\title{
Developing Graduates' Collaboration Skill Based on Islamic Perspective through Integrated Multi-Disciplinary Course in the Built Environment
}

\author{
Fadzidah Abdullah, Aida Kesuma Azmin, and Nurul Hamiruddin Salleh
}

\begin{abstract}
Islam encourages collaboration in all aspects of life, in which leadership and teamwork play important roles. This Islamic obligation is pursued by the Malaysian Ministry of Higher Education's "Teaching and Learning Taxonomy;" in which leadership and teamwork are among some of the basic soft skills that must be developed throughout the students' study duration of the Malaysian students in tertiary educational institutions. Thus, the architecture faculty takes the challenge by instigating collaborative setting in most of the courses offered. This paper aims to discuss on Islamic perspective of collaboration, with special reference to the Integrated Multi-disciplinary course. It has the objective to examine the effectiveness of the Integrated Multi-disciplinary course, in instilling collaborative capability of leadership and teamwork, among undergraduate architectural students at International Islamic University Malaysia (IIUM). This research uses quantitative method to achieve its objective. Questionnaires were distributed among all architectural students who took the course, with $n=105$. Two-third of the respondents either agreed or strongly agreed that the Integrated Multi-disciplinary Course has effectively developed students' leadership and teamwork skills. Indeed, the application of the Islamic standpoint on collaborative setting of architectural education would develop better graduates to lead the ummah, particularly in the Islamic built-environment.
\end{abstract}

Index Terms-Architectural education, collaborative skill, leadership skill, Islamic built-environment, teamwork skill.

\section{INTRODUCTION}

Islam gives guides for Moslems to conduct our lives. Islam encourages collaboration in all aspect of life, in which leadership and teamwork play important roles. This Islamic obligation is pursued by the Malaysian Ministry of Higher Education's (MOHE) requirement in its "Teaching and Learning Taxonomy." Elements of collaboration consisting of leadership and teamwork skills are amongst some of the basic soft skills that must be developed throughout the students' study duration in the Malaysian tertiary educational institutions.

Particularly in the architectural education, developing students' collaborative skills is important to ensure graduates have the proficiency required by the architectural practice.

Manuscript received June 13, 2013; revised August 3, 2013. This work was supported in part by International Islamic University Malaysia under Grant EDW B10-065-0404.

Fadzidah Abdullah, Aida Kesuma Azmin, and Nurul Hamiruddin Salleh are with Department of Architecture, Kulliyyah of Architecture and Environmental Design, International Islamic University Malaysia, 53100 Kuala Lumpur, Malaysia (e-mail: fadzidah@iium.edu.my; aida_kesuma@iium.edu.my; hamiruddin@iium.edu.my).
Thus, the Kulliyyah (faculty) of Architecture and Environmental Design (KAED) of International Islamic University Malaysia (IIUM), takes the challenge by instigating collaborative setting in most of the courses offered. Specifically in the course of AQS 1301: Integrated Multi-disciplinary Project, leadership and teamwork skills are enhanced by instilling collaborative nature to the course. All undergraduates students in the Kulliyyah (faculty), regardless of which department there are in, must enroll in the course in the fulfillment of the requirement for their undergraduate degree.

The course is designed to familiarize the second year architecture students with the real practice environment, where they have to work collaboratively with students from other disciplines in the built environment namely, quantity surveying, landscape architecture, and applied arts and design. The course have been incorporated in the IIUM architectural programs for twelve years, but the effectiveness of enhancing students' collaborative skill has never been scrutinized empirically.

Hence, this paper aims to investigate on the effectiveness of the collaborative effort done in the conduct of the Integrated Multi-disciplinary course, with focus on instilling leadership and teamwork skills among the architecture students. The specific objectives of the research are to evaluate whether the course has effectively developed students' leadership skills; and to assess if the course does instill teamwork skills among students. Hopefully, this research would give some directions on the improvement of architectural education.

\section{LITERATURE REVIEW}

\section{A. Background}

Collaboration skills enhanced in teamwork environment are the key to working effectively with others in workplace or in life, while leadership skills are the key ingredient in management. Accordingly, research in education has clearly demonstrated the benefits of collaborative learning for the development of students' critical thinking as well as the development of self-concepts, social skills, personal responsibility, values and self-attitudes [1].

Collaboration by virtue, means working together especially in a joint intellectual effort [2]. In architecture discipline, Lehmann [3] states that collaboration produces interface between disciplines that are both "innovative and mutually reflexive." He perceives that by having interdisciplinary collaboration, individuals are exposed to new knowledge and 
insights from other disciplines. Odile Decq, the Director General at Ecole Special d'Atchitecture in Paris, mentioned that architecture today is no longer a closed discipline, but it embraces diversity with other disciplines. Thus, he views that architect must be more engaged in inter-trans disciplinary collaboration to have new creativity, to push back the limits, and explore through the unknown [4].

The need to instill collaborative capability among architectural students is essential because the success of architects is dependent upon the application of knowledge from multiple disciplines and perspectives. Architectural education should include encouraging collaboration and communication within and beyond the scope of the design studio. Parnell [5] mentioned that collaboration is supposed to be the strength of the architectural profession.

In professional practice, leadership refers to the process of influencing and supporting others to work enthusiastically toward achieving objectives and major factor for the success of any organization. Accordingly, Mohd Ather and Farid [6] state that leadership involves three basic elements; a leader who guides other person; a group of followers who respond to such guidance; and a situation or objectives to be achieved by coordinating the efforts of many persons.

Thus, education is an important catalyst in developing both collaboration, or so-called teamwork, and leadership skills. Higher education is important not only for generating knowledge base for finding solution to environmental problems, but also for transmitting the skills needed to find gainful manpower. This would contribute to the sustainable future; with talented, relevant, skillful and sufficient manpower to a nation [7].

\section{B. Collaboration Based on Islamic Principles}

Islam encourages collaboration and teamwork in all aspect of life. A team from an Islamic point of view may be defined as a group of people under a team leader who work together on a continuing mission with common (halal) goals and objectives. The concept of the teamwork does not mean individual is no longer important; however it means that effective and efficient teamwork goes beyond individual accomplishments. Working together with team spirit is an Islamic directive and been stressed by the Prophet Muhammad s.a.w. (peace be upon him). It is mentioned in several Hadith (the Muslim's prophet, Muhamad's s.a.w. teachings and sayings), such as [8]:

"The hand of Allah is with the team (Jama'ah). Then, whoever singles himself out (from the Jama'ah) will be singled out for the Hell-Fire"

"Faithful believers are to each other as the bricks of a wall, supporting and reinforcing each other. So saying, the Prophet Muhammad (pbuh) clasped his hands by interlocking his finger"

The concept of Shura (discussion) is also a part of Islamic teaching. In relation to teamwork working environment, Islam considers Shura as a very important principle to achieve the goal or objectives of an organization. As a concept and as a principle, Shura in Islam does not differ from democracy [9]. Walker [10] from the American Muslim Society defines Shura as "helping to get the best out of something," and "pointing to the right choice." Shura should be practiced not only in state affairs, but also in any matters related to human life. Based on Islamic teaching, shura would be used when there is no guide from the Quran and Sunnah (hadith), for example in planning and setting strategies for the development of the state or community. Allah (s.w.t) describes the believers as:

"Those who hearken to their Lord, and establish regular prayers; who conduct their affairs by mutual Consultation; who spend out of what. We bestow on them for Sustenance" [11].

In conjunction with the Islamisation of knowledge championed by IIUM, architectural education too should be structured based on the Islamic framework of collaborative effort to ensure that knowledge, skills and spiritual development are mutually shared and realigned with the practicing world.

\section{Collaboration in Architectural Education}

In order to become proficient architects, graduates are required to gain the skill of monitoring and working collaboratively with many parties; such as quantity surveyors, landscape architects, planners, and engineers. The need to instill collaborative capability amongst architectural students is essential because the success of architects is dependent upon the application of knowledge from multiple disciplines. Architectural education should include encouraging collaboration and communication within and beyond the scope of the design studio. This concern for collaborative issues is acknowledged by the 1999 RIBA Review of Architectural Education, stating that "more team play" is needed to avoid architectural education from continuing being "too referential and self-indulgent" [12]. Boyer and Mitgang [13] suggest that making connections between architecture and other disciplines on campus might serve as a challenge confronting architectural education.

Unfortunately, numerous architecture schools have not been preparing their students in the skills needed in collaborative process. Instead, many schools are focusing on the design studio, where students normally work long hours on their drawing boards. As a result, the students become isolated from the outside world and only know how to communicate with other architects. This educational custom might be followed through to the educational practice. For example, Sergio [14] suggests that some architects tend to assume that the environmental aspects of buildings were the role of the engineering profession. Thus, although the environmentally responsive design and efficient energy buildings have been taught at many schools of architecture, graduates do not feel they are as responsible as those in the engineering profession.

Similarly, Howe's [15] perceives collaboration and teamwork have been the "buzz-words' in the construction industry, yet the evidence of architectural education practicing such notion in architectural instructional design is very limited. He stated that the major cause of non-collaboration in the building industry is the existence of "adversarial professional attitudes" that was inculcated by single discipline staff in higher education. Thus, architectural 
education has been blamed for promoting "primacy of the autonomous designer by focusing all its attention on the student's experience as an individual" [16], rather than promoting collaboration and teamwork.

Development of collaborative skill is required in architectural education, in accordance to its "absolute necessity in professional practice" [17]. To undertake the challenge addressed by Boyer and Mitgang, architectural education has the choice of examining what multi-disciplinary education has to offer for the improvement of architectural education. Here, multidisciplinary means composed of, or combining several usually separate branches of learning or fields of expertise [18]. In the context of architectural profession, multidisciplinary combines fields of professions in the construction industry; including professions of landscape architects, quantity surveyors, urban planners, engineers as well as interior designers.

The learning climate of architectural education should be realigned around different relationships that emphasize the importance of communication, collaboration, and self-reliance. Research in education has clearly demonstrated the benefits of collaborative learning for the development of students' critical thinking as well as the development of self-concepts, values, social skills, personal responsibility, and self-attitudes.

In any collaboration, the spirit of leadership and teamwork are very important. People in a team working together under a team leader, mutually interact and connect with each other in order to achieve organizational goals. Each team member contributes their particular skills and knowledge. Everyone in a team is expected to take responsibility for the success of the team as a whole. The concept of the teamwork does not mean that the individual is no longer important; however it means that effective and efficient teamwork goes beyond individual accomplishments. On the other hand, a leader should guide other members of a team to achieve a certain goal by coordinating the efforts of many persons [19].

At IIUM, the course Integrated Multi-disciplinary Project is designed to familiarize architecture students with the collaborative nature of practice environment, where students from various disciplines in built environment work together to produce building design scheme. The disciplines involved in the course are Architecture, Landscape Architecture, Planning, Quantity Survey, and Applied Art and Design. This course encourages collaboration and communication among students from the alleged disciplines.

\section{Methodology OF ReSEARCH}

This research uses quantitative methods to achieve its objectives. Survey is conducted to get generalization of ideas on the effectiveness of the course in enhancing students' teamwork and leadership skills. About 300 students from several departments in the faculty registered for this course in that particular semester, but the questionnaires were distributed among architectural students only, as they were the main focus of this research. All architectural students undertaking the course responded to the survey, with $n=105$.

Eighteen (18) questions were formulated, which were categorized into four (4) main sections or categories, which are category A, B, C, and D. Section A focused on demographic questions, while section $\mathrm{D}$ had only one qualitative open- ended question, which would be used for different research. Only sections B and C are relevant to the discussion of this paper. In both sections, structured questions were formulated using five Point Likert-scales, where students had to choose their answer based on their level of agreement to the addressed statements. Those numbers are 1 , 2, 3, 4 and 5; where 1 represented strongly agrees, 2 represents agree, 3 represents natural opinion, 4 represents disagree, and 5 represents strongly disagree. Using this method was a strategy to get respondents to respond quickly and conclusively.

All the respondents were the second year architectural students who registered for the Integrated Multi-disciplinary course. With all registered students responded to the survey, this research is considered to provide valid generalization of ideas in-term of the effectiveness of the course in enhancing students' teamwork and leadership skills.

\section{RESEARCH FINDINGS}

\section{A. Leadership Skill}

The majority of the students $(52.4 \%)$ agreed that the Integrated Multi-disciplinary Project has effectively developed student's leadership skill. This shows that, the course is successful in providing a platform for student to enhance their leadership skill. The largest percentage of the student $(42.9 \%)$ agreed that the course enhances one's confidence and ability to monitor and coordinate a group of student for any given task. Therefore, it is clear that the Integrated Multi-disciplinary Project is an important subject which contributes to boost students' confidence in leadership.

The highest percentage of the students $(36.2 \%)$ disagree that course does not allow them to reveal their leadership skills. Therefore, it is also proven that the course is a place for students to reveal their leadership skills. Majority of the student $(41.9 \%)$ agreed that after completing the Integrated Multi-disciplinary Project class, they need more training in order to develop their leadership skills. This is because, the course of Integrated Multi-disciplinary Project is just a preliminary platform, and they need more training in the real project, in order to expand their leadership potential.

A high percentage of students $(43.8 \%)$ are undecided that based on their experience in the Integrated Multi-disciplinary Project, they prefer not to be the leader in construction project. This might happened because they do not have a very clear thought on the responsibility of a leader in a real construction project.

\section{B. Teamwork Skill}

The two-third of the students $(68.6 \%)$ agreed that the course of the Integrated Multi-disciplinary Project has effectively developed their teamwork skill. This shows that the course is a successful group-based learning project that can educate students in teamwork. The majority of the students $(45.7 \%)$ also agreed the course enhances their teamwork skill in which they are now able to be effective 
leaders for any given task. Therefore, it proves that the course is an effective learning process that enriches students' confidence to be efficient leaders for any given project.

A great percentage of students $(59.0 \%)$ agreed the Integrated Multi-disciplinary Project enhances their teamwork skill that they are now able to be effective followers for any given task. It is clearly shown that the Integrated Multi-disciplinary Project is not only effective for leadership training, but at the same time, trained each student to be a good follower and contributor to their group. Most of the students $(45.7 \%)$ disagreed that their task in the Integrated Multi-disciplinary Project does not allow them to reveal their teamwork skill. Therefore, it is clearly shown that the Integrated Multi-disciplinary Project allows student to expose their skill of working in a team.

The highest percentage of students $(38.1 \%)$ agreed that after completing the Integrated Multi-disciplinary Project class, they still need more training in other to develop their teamwork skill. This is because, the course is just an initial platform that represents a teamwork project, but they need more training in a real project in order to improve their teamwork skills.

\section{CONCLUSION}

The Integrated Multi-disciplinary Project has successfully provided students with not only technical knowledge, but also with the leadership and teamwork skills required to work in real-life projects. Students generally agree that the course has successfully developed students' leadership skills, and instilled teamwork skills among students. The course is important not only for generating knowledge base for finding solution to architectural and built-environmental problems, but also for transmitting the skills needed to find gainful manpower and ultimately contribute to the sustainable future.

Leadership and teamwork skills are valuable qualities in the learning process of architecture. Even though the collaborative method is apparently full of obstacles, these factors should be seen as challenges, which can be overcome through training and experience. The effectiveness of collaborative learning in architectural education shall be the result of appropriate design of the learning process in order to stimulate future professional skills with adequate methods and techniques.

In general, the findings of this research contribute to the improvement of the collaborative nature and to the enhancement of quality in architectural education. Thus, it is hoped that this research could provide a more focused direction and mode of actions to be incorporated in the development of instructional design of architectural education so as to include collaborative endeavors.

\section{REFERENCES}

[1] D. Nicol and S. Pilling, Changing Architectural Education: Towards a New Professionalism, London: Spoon Press, 2000.

[2] Farlex. (November 2012). The Free Dictionary. [Online]. Available: http://www.thefreedictionary.com/collaboration

[3] S. Lehmann, "Interdisciplinary models for collaboration between artists and architects: Empowering community, inspiring urban renewal," UNESCO Observatory, Faculty of Architecture, Building and Planning, the University of Melbourne refereed e-journal, vol. 1, issue 4, 2007.
[4] R. Arribas. (November 2011). Speech Manuscript of Odile Decq, Director General at Ecole Special d'Atchitecture in Paris. International Architectural Education Summit 2011. [Online]. Available: http://news.university.ie.edu/2011/06/international-architectural-educ ation-summit-2011-outcomes.html

[5] R. Parnell, "Knowledge skills and arrogance: Educating for collaborative practice," EAAE Transaction on Architectural Education, no. 15, 2003.

[6] S. M. Ather and F. A. Sobhani, "Managerial leadership: An Islamic perspective," IIUC Studies Journal, vol. 4, International Islamic University Chittagong, 2007.

[7] M. Aslam, Selamah, and Ruzita, "Values, market needs and higher education curriculum: The quest for comprehensive development," in International Proceedings the 6th. Global Conference on Business and Economics, Gutman Conference Centre, USA. 2006.

[8] S. Al Bukhari, Hadith, translated by H. Z. Hamidy, Klang: Klang Book Centre, 1997.

[9] J. S. Sadek, "Democracy and shura," United States: Al-Hewar Centre, Inc. 1999.

[10] A. H. Walker. (2013). Shura mutual consultation. [Online]. Available: http://www.alislam.org/topics/khilafat/Shura.pdf

[11] Al-Quran, Translated by Abdullah Yusuf Ali. Kuala Lumpur: Islamic Book Trust, 1994.

[12] C. Stansfield-Smith, Architectural Education for the 21st. Century, London: Royal Institutes of Architects, 1999.

[13] L. Boyer and L. Mitgang, Building Community: A New Future for Architectural Education and Practice, Princeton, New Jersey: The Carnegie Foundation For the advancement of Teaching, 1996.

[14] A. Sergio, "Environmental education for sustainable architecture," Review of European Studies Journal, vol. 1, no. 2, Department of the Built Environment, University of Nottingham, UK.

[15] J. Howes, "Is working together working?" in Changing Architectural Education: Towards a New Professionalism, eds., D. Nicol and S. Pilling, (London: Spoon Press), 2000, pp. 241-260.

[16] D. Cuff, Architecture: The story of Practice, Cambridge: Mass. MIT Press, 1991.

[17] T. Fisher, "Can this profession be saved?" Progressive Architecture, vol. 75 , no. 2, pp. 44-49, 1994

[18] Dictionary.com. (November, 2012). Multidisciplinary. [Online]. Available: http://dictionary.reference.com/browse/multidisciplinary?s=t

[19] Akramulla. (April, 2012). Islamic Leadership, Islam and Teamwork. [Online]. Available: http://www.hotfreebooks.com/book/The-Promise-Of-American-LifeHerbert-David-Croly.html

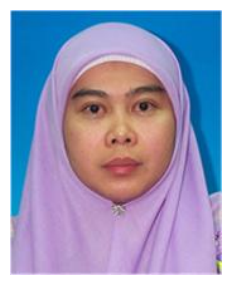

Fadzidah Abdullah was born in Johor, Malaysia, on August $10^{\text {th }}$. 1968. Fadzidah obtained her PhD in Architecture from University of Strathclyde, Glasgow, Scotland, United Kingdom, in 2006. Fadzidah previously obtained her Master of Science Degree in Computer aided Environmental Design (CAED), in 2000, from School of Architecture, University of Sheffield, England, United Kingdom. Her Bachelor of Architecture was obtained from Texas Tech University, Texas, USA, in 1992.

She worked in architectural private firm for three years upon obtaining her first degree. Later, she joined the Malaysian Public Work Department, working as an architect for another three years. She decided to join in academic realm in 1998. Presently, she is an active academic member at Kulliyyah (Faculty) of Architecture \& Environmental Design (KAED), International Islamic University Malaysia (IIUM), Kuala Lumpur, Malaysia.

Dr. Fadzidah's research interest is on the areas of Architectural Education, Inclusive Design, Healthcare Design, and Heritage Study. She is active in research writing, has co-authored 11 books thus far, and had presented numerous conference papers internationally. She is interested to have joint research venture with worldwide architectural network.

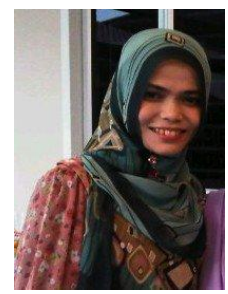

Aida K. Azmin was born in Kangar, Perlis, Malaysia on March $21^{\text {st }}, 1973$. Azmin obtained her PhD in Architecture from Edinburgh College of Art Research School, Heriot-Watt University, Edinburgh, Scotland, UK, in 2007. Her first Degree in Architecture (International) was obtained from University of Huddersfield, West Yorkshire, UK in 1998.

She worked as a design architect before joining IIUM's department of Architecture as assistant 
lecturer in November 1999. Presently, she is an active academic member, an Assistant Professor/ Lecturer in Architecture at Kulliyyah (Faculty) of Architecture \& Environmental Design (KAED), International Islamic University Malaysia (IIUM), Kuala Lumpur, Malaysia.

Research Interests include: Cultural Architecture, Heritage Studies, and Social Environmental Behaviour Architecture.

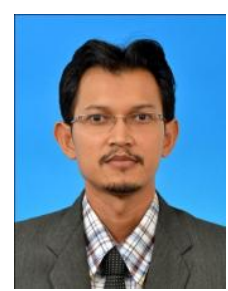

Nurul Hamiruddin Salleh is the current head of Department, the Department of Architecture, Kulliyyah of Architecture and Environmental Design, International Islamic University Malaysia, Kuala Lumpur. He has a Diploma in Architecture and Bachelor in Architecture (Hons) degree in 1996 and 2000, respectively from Universiti Teknologi Malaysia, Johor, Malaysia. In 2003, he was awarded Master of Arts in Conservation Studies (Historic Buildings and Places) from University of York, York, United Kingdom. In 2011, he was awarded Doctor of Philosophy (Ph.D) in Architecture (Building Conservation) from Universiti Sains Malaysia, Penang, Malaysia.
His research interest includes heritage buildings conservation, building fire safety, building technology and, architectural documentation and recording. He is a member of the International Council on Monuments and Sites (ICOMOS), the Board of Architects Malaysia (LAM) and the Malaysian Institute of Architects (PAM).

Nurul Hamiruddin is active in publication, research, supervision and consultancy. He has won one gold award and two bronze awards in research and innovation exhibition. He also was awarded Gold: Best Lecture (Architecture) in Nippon Young Designer Award 2012. He has co-authored 3 books and presented more than 10 papers on heritage fire safety and building conservation in national and international conferences. 